\title{
NEPAKALTINAMŲ ASMENŲ PAKARTOTINIO NUSIKALSTAMUMO IR ĮGALINIMO SĄSAJOS
}

\author{
Jolanta Navickiené ${ }^{1}$, Algimantas Liausėdas ${ }^{1}$, Edmundas Vaitiekus ${ }^{2}$ \\ ${ }^{1}$ Viešoji ịstaiga Rokiškio psichiatrijos ligonine, ${ }^{2}$ Utenos kolegija
}

Raktažodžiai: nepakaltinamas asmuo, pakartotinis nusikalstamumas, rizikos veiksniai, igalinimas.

\begin{abstract}
Santrauka
Pastaraisiais dešimtmečiais vykdoma daug tyrimų, kuriuose nagrinėjama nusikalstamos veikos priežastys, rizikos veiksniai, lemiantys pasikartojanti nusikalstamumą. Pakartotinis nusikalstamumas - nuolatinė tendencija pakartotinai nusikalsti, elgtis asocialiai.

Veiksniai, turintys itakos pakartotiniam nusikalstamam elgesiui, yra žemas išsilavinimo lygis, baziniu igūdžių neturèjimas, užimtumo darbo rinkoje problemos, nuolatinès gyvenamosios vietos neturejjimas, narkotikų ir alkoholio vartojimas, psichinès sveikatos sutrikimai, silpni socialiniai ryšiai. Esminis šių veiksnių pakartotinius nusikaltimus skatinantis vaidmuo patvirtintas įvairiose šalyse atliktu tyrimų rezultatais. Dèl to yra pagrindas manyti, kad šie veiksniai universalūs.

Straipsnio tikslas - atskleisti nepakaltinamų asmenų pakartotiniam nusikalstamumui įtakos turinčius rizikos veiksnius bei šių asmenų pakartotinio nusikalstamumo sąsajas su igalinimu. Taikyti tyrimo metodai - mokslinès literatūros bei Rokiškio psichiatrijos ligoninès pacientų dokumentų analizè.

Tyrimas parodè rizikos veiksnių itaką tiriamujų nusikalstamumui bei menkas tiriamųų igalinimo išorines sąlygas. Rizikos veiksniai, skatinantys nepakaltinamų asmenų pakartotinį nusikalstamumą, susiję su šių asmenų ịgalinimu - pasirinkimų didinimu bei galimybėmis paveikti savo gyvenimą.
\end{abstract}

\section{İvadas}

Visuomenès saugumas - prioritetinis kiekvienos valstybės tikslas, o galimybè atskirti asmenis, kurie kelia grésmę visuomenei - viena iš teisinès sistemos siekiamybių. Nusikalstamumas - viena iš aktualiausių socialinių problemų, su kuria susiduria kiekviena šalis [8]. Pastaraisiais dešim- tmečiais vykdoma daug tyrimų, kuriuose nagrinejjama nusikalstamos veikos priežastys, rizikos veiksniai, lemiantys pasikartojantį nusikalstamumą. Pakartotinis nusikalstamumas - nuolatinè tendencija pakartotinai nusikalsti, elgtis asocialiai [8]. Siekiant mažinti pakartotinio nusikalstamumo statistiką, tikslinga atkreipti dėmesị ị asmenų resocializaciją bei didesnį dèmesị skirti asmenų ịgalinimui.

Šiuolaikinei nusikalstamumo prevencijos problemos sprendimo versijai, vyraujančiai visuomenejje, būdinga nuomone, kad nusikalstamumo prevencija yra pirmiausia teisèsaugos institucijų pareiga. Taip pat manoma, kad tik teisèsaugos institucijų veiksmingas ir tinkamai organizuotas darbas iš esmès užtikrina nusikalstamumo prevencijos sèkmę šalyje. Ši nuomonè, nors ir plačiai paplitusi bei žiniasklaidos eskaluojama, kriminologiniu požiūriu atrodo klaidinga [5].

Lietuvos Respublikos Vyriausybè 2012 m. lapkričio 14 d. nutarimu Nr. 1381 patvirtino Nacionalinès nusikaltimų prevencijos ir kontrolès programos igyvendinimo tarpinstitucinį veiklos planą, kuriame vienu iš veiklos prioritetų išskirta,$<\ldots>$ nusikalstamumo prevencijos sistemos tobulinimas per mokslinius tyrimus; $<\ldots$.. “. Tai svarbus iššūkis tiek mokslininkams, tiriantiems nusikalstamumą ir su juo susijusius socialinius procesus, tiek ir praktikams, kurie, esant ribotiems finansiniams bei žmogiškiesiems ištekliams, siekia užtikrinti saugumą bendruomeneje ir valstybeje [5].

Pakartotinis nusikalstamumas. Pakartotinis nusikalstamumas - nuolatinè tendencija pakartotinai nusikalsti, elgtis asocialiai [8]. Tiriant pakartotinio nusikalstamumo rodiklius ir su tuo susijusius veiksnius, susiduriama su daugeliu problemų. Vis dèlto šiuolaikinèje mokslinèje literatūroje daugiausia dèmesio skiriama ne pakartotinio nusikalstamumo sampratos problematikai, bet asmens keliamos rizikos ivvertinimui. Dažniausiai bandoma ịvertinti, kokie veiksniai lemia, ar asmuo pakartotinai nusikals, bei kurie iš tų veiksnių yra reikšmingiausi. Pakartotinai nusikalstančio asmens (recidyvisto) asmenybe - tai visuma tarpusavyje susijusių socialiai reikšmingų neigiamų savybių ir santykių, kurie sąveikaudami su išorinèmis sąlygomis ir aplinkybèmis, 
nulemia pakartotinių nusikalstamų veikų padarymą [5].

Nusikalstamumo procesus analizuojančios mokslinès studijos siekia išsiaiškinti ne tik nusikalstamo elgesio prigimtį, jo pasireiškimo variantus, bet ir žinių apie su nusikalstamu elgesiu susijusius biologinius, asmeninius, tarpasmeninius, situacinius ir socialinius kintamuosius. Šie nusikalstamą elgesi prognozuojantys veiksniai dar yra vadinami rizikos veiksniais ir remiasi žmonių bei jų situacijų charakteristikomis, kurios yra susijusios su didesne nusikalstamo elgesio tikimybe [8].

Rizikos veiksnių itaka pakartotiniam nusikalstamumui. Naujausiuose moksliniuose tyrimuose, nagrinėjančiuose pasikartojančio nusikalstamo elgesio prigimtị ir jo priežastis, dažniausiai skiriami konkretūs teisès pažeidejjo pakartotinio nusikalstamumo rizikos veiksniai, kurie skirstomi i dvi grupes. Viena iš jų yra statiniai veiksniai (laikui bėgant nesikeičia), antroji - dinaminiai (besikeičiantys). Dinaminiai rizikos veiksniai dar apibūdinami kaip kriminogeniniai poreikiai. Juos patenkinus, sumažeja pakartotinio nusikalstamumo rizika [7].

Statiniai rizikos veiksniai. Statiniai veiksniai apima praeityje ivvykusius ir dèl to nekintamus, su nusikalstamu elgesiu sietinus reiškinius bei faktus [7]. Mokslinejje literatūroje statiniams rizikos veiksniams priskiriama kriminalinio elgesio istorija - anksti prasidejjęs ir nenutrūkstamas dalyvavimas nusikalstamoje veikloje ịvairiomis aplinkybėmis ir įvairiose situacijose [8]. Teisès pažeidejo amžius pirmojo nusikaltimo metu taip pat yra statinis rizikos veiksnys ir ypač reikšmingas ne tik apibūdinant teisès pažeidèjo nusikalstamumo istoriją, bet ir prognozuojant pakartotini nusikalstamumą [8]. Reikšmingas statinis veiksnys - asmens biologinès šeimos kriminalinè istorija. Jeigu šeimos narių elgesys asocialus, jie pažeidinèjo įstatymus, tai toks vaikystejje ar paauglystèje išmoktas nusikalstamas elgesys turi tendenciją išlikti ir vẻliau. Asmens iggalinimo objektu negali būti statiniai veiksniai, nes jie yra stabilūs ir jų pakeisti negalima.

Dinaminiai rizikos veiksniai. Tradiciškai dinaminiai rizikos veiksniai ar kriminogeniniai poreikiai yra skirstomi i asmeninius, socialinius ir ekonominius [8]. Toks veiksniu grupavimas atspindi specifiką ir sritis, kurioms jie priklauso. Mokslinèje literatūroje minimi šie dinaminiai rizikos veiksniai: išsilavinimas, darbas, gyvenamoji vieta (būstas), finansai, santykiai su partneriu ir artimaisiais, alkoholio/ narkotikų vartojimas, psichikos sveikata.

Analizuojant nepakaltinamų asmenų dinaminius rizikos veiksnius, galima išskirti dar vieną veiksnį, glaudžiai susijusi su psichikos sveikata - tai priverčiamųų medicinos priemonių (toliau - PMP) taikymas. PMP skiriamos asmenims, teismo pripažintiems nepakaltinamais ar ribotai pakaltinamais, arba asmenims, kuriems po nusikalstamos veikos padarymo ar bausmès paskyrimo sutriko psichika ir dèl to jie negali suvokti savo veiksmų esmès ar jų valdyti. Po PMP taikymo uždaro tipo gydymo įstaigoje, psichikos sutrikimu turintiems asmenims yra sunku prisitaikyti prie visuomenès gyvenimo sąlygų, todèl reikalinga visokeriopa pagalba integruojantis šiuolaikinejje socialinejje aplinkoje.

Taigi, mokslinès literatūros ir mokslinių tyrimų analizè nurodo grupę veiksnių, turinčių didelès įtakos pakartotiniam nusikalstamam elgesiui: žemas išsilavinimo lygis, bazinių ịūdžių neturejjimas; užimtumo darbo rinkoje problemos (darbo pastovumas bei pasitenkinimas juo); nuolatinès gyvenamosios vietos neturèjimas; narkotiku ir alkoholio vartojimas; psichinès sveikatos sutrikimai; silpni socialiniai ryšiai (socialinis kapitalas).

Esminis šių veiksnių pakartotinius nusikaltimus skatinantis vaidmuo patvirtintas įvairiose šalyse atliktų tyrimu rezultatais. Dėl to yra pagrindas manyti, kad šie veiksniai yra universalūs. Jų ịtaka turètų būti svarbi taip pat ir tose šalyse, kur tokie tyrimai dar nebuvo atliekami, taigi ir Lietuvoje [2].

Igalinimas. Viena iš pasiteisinančių pagalbos priemonių, siekiant sumažinti ar užkirsti kelią pakartotiniam nusikalstamumui - igalinimas. Igalinimas - procesas, kurio metu žmonès ar bendruomenès padidina savo gyvenimo kontrolę ar jo kūrimą, dalyvavimą sprendimuose, liečiančiuose jų gyvenimą [1]. Igalinimas, kaip teigia L. C. Johnson, - tai strategija, kurios tikslas - ,sumažinti žmogaus bejègiškumą, skatinti imtis atsakomybès už savo gyvenimą“" [6]. Dabartinès lietuvių kalbos žodyne igalinimas apibrěžiamas kaip leidimas kažką daryti. Igalinimas - platus, daugiadimensinis ir multidisciplininis reiškinys [3]. Dažniausiai psichikos negalią turinčių asmenų igalinimas siejamas su psichosocialine reabilitacija, kuri apibrěžiama kaip procesas, kuris suteikia individams galimybę pasiekti optimalų savarankiškumo lygị.

Igalinimu siekiama sumažinti žmogaus, atsidūrusio probleminèje situacijoje, bejègiškumą, skatinama keistis ir keisti savo aplinką, kritiškai ir atsakingai mąstyti bei veikti, suteikiama pasirinkimo galimybių laisve, reikiamos žinios, igūdžiai, ištekliai, drauge skatinama prisiimti atsakomybę už savo poelgius ir gyvenseną. Igalinimo turinị apibūdina prasmingi socialiniai ryšiai, pasikeitimas žiniomis, darbuotojo ir kliento nuoširdus bendravimas, dialogas bei partneryste, paremta pagarba, tolerancija, nuoširdumu, disciplinuotumu ir atsakomybe [10].

Platūs užsienio valstybėse atlikti recidyvinio nusikalstamumo priežasčių tyrimai leido išaiškinti veiksnius, kuriuos kryptingai taikant galima pastebimai sumažinti pakartotinio nusikaltimo padarymo tikimybę. Svarbiausi iš jų: bazi- 
niai gyvenimo igūdžiai bei išsilavinimas, užimtumo darbo rinkoje statusas, turimo darbo kokybè, nuolatinès gyvenamosios vietos turejjimas, psichikos sveikatos būklè, socialiniai ryšiai. Priemonès, skirtos šiems veiksniams kontroliuoti, tapo modernių vietinių ir nacionalinių pakartotinio nusikalstamumo prevencijos programų pagrindu [2].

Daugelio autorių atlikti moksliniai tyrimai patvirtina, kad netgi sergantys šizofrenija arba alkoholizmu asmenys geriau funkcionuoja bendruomeneje: tie, kuriuos sieja palaikantys ryšiai, ilgiau jaučia gydymo rezultatus, mažiau atsinaujina ligos ir rečiau guldomi į ligoninę. Ir priešingai, socialiai izoliuoti arba gaunantys nepakankamą socialinę paramą individai, susidūrę su problemomis, rečiau imasi aktyvių veiksmų joms spręsti. Socialiniai ryšiai, stiprinantys socialinį tinklą, parodo socialinius išteklius, esančius bendruomenejje ir galinčius suteikti paramą krizès atveju [10].

Straipsnio tikslas - atskleisti nepakaltinamų asmenų pakartotiniam nusikalstamumui įtakos turinčius rizikos veiksnius bei šių asmenų pakartotinio nusikalstamumo sąsajas su igalinimu.

\section{Tyrimo medžiaga ir metodas}

Siekiant ịgyvendinti darbo tikslą, atlikta mokslinès literatūros analizè ir sociologinis tyrimas VŠI Rokiškio psichiatrijos ligoninejje. Tyrimo metodas - dokumentų (teismo psichiatrijos, teismo psichologijos ekspertiziu aktų, epikrizių, teismo nutarčių, buities tyrimo aktų, raštų iš įvairių institucijų ir kt.) analize. Buvo renkama informacija apie: nepakaltinamą asmenị (amžius, lytis, išsilavinimas ir kt.); respondento sveikatą (diagnozé, darbingumo lygis, psichi-

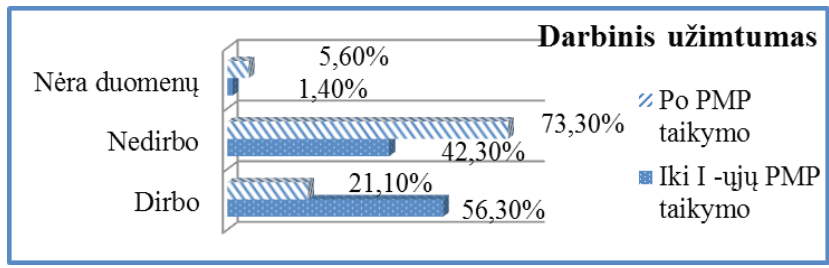

1 pav. Tiriamujų pasiskirstymas pagal darbinį užimtumą iki I ujų PMP ir po PMP taikymo, procentais

1 lentelė. Tiriamujų pasiskirstymas pagal santuokinio statuso ir PMP ryšį, procentais

\begin{tabular}{|l|l|l|l|}
\hline \multirow{2}{*}{ Santuokinis statusas } & \multicolumn{3}{|c|}{ PMP taikomas } \\
\cline { 2 - 4 } & II kartą & III kartą & IV kartą \\
\hline Gyvena nesudarę santuokos & $1,4 \%$ & & \\
\hline Našlys (-è) & $2,8 \%$ & & \\
\hline Išsituokęs (-usi) & $19,7 \%$ & $1,4 \%$ & $2,8 \%$ \\
\hline Nevedęs (netekẻjusi) & $\mathbf{4 9 , 3 \%}$ & $\mathbf{1 5 , 5 \%}$ & $\mathbf{2 , 8 \%}$ \\
\hline Vedęs (ištekėjusi) & $1,4 \%$ & $2,8 \%$ & \\
\hline
\end{tabular}

kos sutrikimo pripažinimas); šeimyninę padètį bei socialinius santykius (vedybinis statusas, nuolatinio partnerio turèjimas/neturèjimas, socialinius ryšius iki PMP ir PMP taikymo metu bei jų pokyčius ir kt.); darbinį užimtumą ir pajamas (gaunamos pensijos/pašalpos pobūdis, darbinis užimtumas iki PMP/po PMP taikymo, nedarbo priežastis ir kt.); nusikalstamą veiką (teistumą, taikytų PMP skaičių, PMP trukmę, ivykdytas nusikalstamas veikas bei jų sąsajas su PMP taikymo skaičiumi ir kt.); resocializacijos (igalinimo) priemones, taikytas hospitalizacijos metu bei bendruomenejje.

Statistinè duomenų analizè atlikta naudojant programos SPSS-21 paketą.

\section{Tyrimo aprašymas ir rezultatai}

Tyrimo metu išanalizuota 71 nepakaltinamo asmens, kuriam 2015 m. 05 - 07 mèn. buvo pakartotinai taikomos PMP griežto, sustiprinto ir bendro stebejjimo sveikatos priežiūros skyriuose, dokumentacija. $74,6 \%$ asmenų $(\mathrm{N}=53)$ PMP taikomos antrą kartą; 19,7\% $(\mathrm{N}=14)$ - trečią, $5,6 \%(\mathrm{~N}=4)$ - ketvirtą ir daugiau kartų. PMP pakartotinai taikytos $91,5 \%(\mathrm{~N}=65)$ vyrams ir $8,5 \%(\mathrm{~N}=6)$ moterims. Daugiau nei puse tiriamųju (61\%) - vidutinio amžiaus asmenys.

Apibendrinant statinius rizikos veiksnius matyti, kad daugiau nei pusé tiriamųjų, kuriems pakartotinai taikomos PMP, augo pilnoje šeimoje (52,1\%), 32,4\% - nepilnoje šeimoje, 11,3\% - institucijose. 5,6\% tiriamujų, kuriems PMP taikomos IV kartą, augo nepilnose šeimose. $65,5 \%$ tiria-

2 lentelè. Tiriamujų pasiskirstymas pagal gyvenimą šeimoje ir PMP taikymo dažnumą, procentais

\begin{tabular}{|l|c|c|c|}
\hline \multirow{2}{*}{$\begin{array}{l}\text { Iki PMP taikymo } \\
\text { gyveno su: }\end{array}$} & \multicolumn{3}{|c|}{ PMP taikomos } \\
\cline { 2 - 4 } & II kartą & III kartą & IV kartą \\
\hline Kitais asmenimis & $1,4 \%$ & & \\
\hline Globos namuose & $\mathbf{1 9 , 7 \%}$ & $\mathbf{8 , 5 \%}$ & $\mathbf{2 , 8 \%}$ \\
\hline Su vienu iš tèvu & $26,8 \%$ & $5,6 \%$ & \\
\hline Su tèvais & $14,1 \%$ & $4,2 \%$ & \\
\hline $\begin{array}{l}\text { Su sutuoktiniu / par- } \\
\text { tneriu (-e) }\end{array}$ & $5,6 \%$ & & \\
\hline Vienas (-a) & $7,0 \%$ & $1,4 \%$ & $2,8 \%$ \\
\hline
\end{tabular}

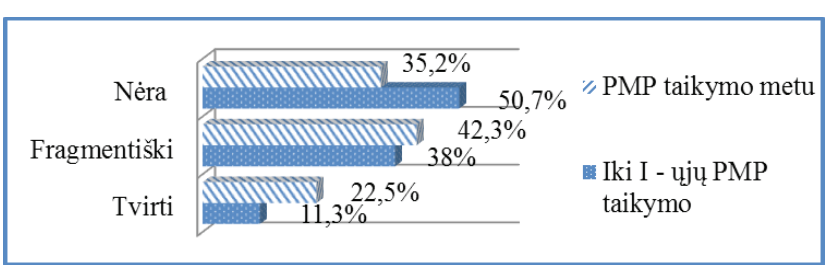

2 pav. Tiriamujų pasiskirstymas pagal socialinius santykius iki PMP taikymo ir jų metu, procentais 
mujų biologinèse šeimose buvo vartojamas alkoholis, bei $26,8 \%$ šeimų buvo smurtaujama.

Dinaminiai rizikos veiksniai. Išsilavinimas. 36,6\% tiriamujų turi pagrindinį išsilavinimą; $23,9 \%$-vidurinį; $22,5 \%$ - aukštesniji ; 5,6\% - aukštaji ; $11,2 \%$ - pradinị arba neturi jokio išsilavinimo. Profesinè kvalifikacija: 49,3\% tiriamujų neturi profesinès kvalifikacijos; $46,5 \%$ yra igiję profesinę kvalifikaciją. Gyvenamoji vieta. Iki I - ujų PMP taikymo $53,5 \%$ respondentų gyveno tèvų/artimujų namuose; $15,5 \%$ nuosavame; $4,2 \%$ - išnuomotame; $26,8 \%$ tiriamujų - socialinès globos namuose.

Darbinis užimtumas. Iki I - uju PMP taikymo 21,1\% tiriamujų nedalyvavo darbo rinkoje, po PMP taikymo nedirbančiųu skaičius išaugo tris kartus (1 paveikslas). Nedarbo priežastys: 73,2 \% tiriamųų dirbti negalèjo dèl sveikatos problemų. Tyrimo rezultatai parode, kad po PMP taikymo stacionare tik maža dalis nepakaltinamų asmenų sugeba išlikti darbo rinkoje. Nedalyvaudami darbinèje veikloje 49,3\% tiriamujų gavo netekto darbingumo pensiją; $47,9 \%$ - socialinę pašalpą, o 2,8\% jokių asmeninių pajamu negavo.

Santuokinis statusas. Tyrimo rezultatai parodè, kad dažniausiai PMP taikomos, 69\% skirta II kartą, 16,9\% - III kartą ir 5,6\% - IV kartą, išsituokusiems asmenims arba nevedusiems (netekejjusioms). PMP dažnumo ir santuokinio statuso ryšio duomenys pateikiami 1 lentelèje.

Socialiniai santykiai ir ryšiai. Iki PMP pakartotino taikymo $11,3 \%(\mathrm{~N}=8)$ tiriamųju gyveno vieni; 5,6\% $(\mathrm{N}=4)$ - su sutuoktiniu/partneriu (-e); 18,3\% ( $\mathrm{N}=13)$ - su tèvais; $32,4 \%(\mathrm{~N}=23)$ su vienu iš tèvų; $31 \%(\mathrm{~N}=22)$ - socialinès globos namuose. Atsižvelgiant ị PMP taikymo dažnumą matyti, kad dažniau PMP buvo taikomos tiriamiesiems, kurie gyveno socialinès globos namuose (2 lentelè).

Iš gautų duomenų matyti, kad nepakaltinamų asmenų

3 lentelè. Tiriamujų pasiskirstymas pagal psichikos sutrikimo bei medikamentinio gydymo pripažinimą ir taikomas PMP, procentais

\begin{tabular}{|c|c|c|c|c|c|}
\hline & \multicolumn{3}{|c|}{ PMP taikomos } & \multirow[t]{3}{*}{ p } \\
\hline & & II kartą & $\begin{array}{c}\text { III } \\
\text { kartą }\end{array}$ & $\begin{array}{c}\text { IV } \\
\text { kartą }\end{array}$ & \\
\hline \multirow{2}{*}{$\begin{array}{l}\text { Pripažįsta } \\
\text { turintys } \\
\text { psichikos } \\
\text { sutrikimą }\end{array}$} & $\mathrm{Ne}$ & $19,7 \%$ & $8,4 \%$ & $4,2 \%$ & \\
\hline & Taip & $54,9 \%$ & $11,3 \%$ & $1,4 \%$ & \multirow{3}{*}{0,002} \\
\hline \multirow{2}{*}{$\begin{array}{l}\text { Pripažịsta } \\
\text { jog reikalin- } \\
\text { gas medi- } \\
\text { kamentinis } \\
\text { gydymas }\end{array}$} & $\mathrm{Ne}$ & $14,1 \%$ & $11,3 \%$ & $4,2 \%$ & \\
\hline & Taip & $60,6 \%$ & $8,5 \%$ & $1,4 \%$ & \\
\hline
\end{tabular}

socialiniai santykiai su šeimos nariais/artimaisiais keitėsi: $11,2 \%$ tiriamujų santykiai sustiprejo PMP taikymo metu, tačiau 4,3\% - jie tapo fragmentiški, bei $15,5 \%$ - nebepalaikè jokių socialinių ryšių su šeimos nariais ar artimaisiais (2 paveikslas).

Iki I - ujų PMP socialinius ryšius su draugais/pažįstamais palaike $50,7 \%$ tiriamujų. Atlikto tyrimo rezultatai parode, kad PMP taikymo metu socialinius ryšius su draugais ar pažistamais palaike tik $11,3 \%$ tiriamujų. PMP taikymas turi neigiamos įtakos socialiniams ryšiams. Galima daryti prielaidą, kad dèl pakartotinai ịvykdytų nusikalstamų veikų susilpnejja tiriamujų socialiniai ryšiai su artimaisiais, o ryšiai su draugais/pažįstamais - nutrūksta.

Psichikos sveikata. Iki I - ujų PMP taikymo 91,6\% tiriamuju jau buvo gydyti psichiatrijos ligoninèse, $7 \%$ - nebuvo hospitalizuoti, apie 1,4\% - nėra duomenų. Tyrimo metu $7 \%$ tiriamujų, kuriems pakartotinai taikomos PMP, nustatytas 0-25\% darbingumo lygis, 93\% respondentu - 30-55\%. Pagal diagnozes pakartotinai taikomų PMP metu tiriamieji pasiskirsté taip: 76,1\% respondentų diagnozė F20-F28, 11,3\% - F04, F06-F07, 8,5\% - F70-79. Tyrimo metu pastebèta, kad didejjant pakartotinai taikomų PMP skaičiui, dideja ir tiriamujų, kurie nepripažįsta turintys psichikos sutrikimą ar medikamentinio gydymo reikalingumo, skaičius (3 lentelè).

Nusikalstama veika. Atliktas tyrimas parodè, kad augant PMP skaičiui, išlieka nepakaltinamų asmenų ịvykdytos sunkiosios nusikalstamos veikos.

Apibendrinus dinaminių rizikos veiksnių įtaką pakartotinam PMP taikymui, galima teigti, kad yra ryšys tarp minètų rizikos veiksnių ir pakartotinio nusikalstamumo. Daugiausia nusikalstamą veiką ịvykdo ir PMP priemonès skiriamos žemesnio išsilavinimo, nedalyvaujantiems darbinèje veikloje, nevedusiems ar išsituokusiems tiriamiesiems, gyvenusiems socialinès globos namuose ar su vienu iš tèvų, nepripažįstantiems psichikos sutrikimo ar medikamentinio gydymo reikalingumo.

Nepakaltinamų asmenų integracija ị visuomenę pradedama gydymo i̇staigoje. Hospitalizacijos metu, kuomet taikomos PMP priemonès, teikiamos kompleksinès paslaugos, kurias sudaro: medikamentinis gydymas ir priežiūra, psichologinè pagalba bei psichosocialinè reabilitacija. Tyrimo metu gauti duomenys rodo, kad būdami stacionare, kuomet taikomos PMP, 91,5\% tiriamujų esant poreikiui kreipiasi pagalbos ị specialistus, 59,2\% respondentu pripažista psichosocialinèje reabilitacijoje taikomas programas, $74,6 \%$ nepakaltinamų asmenų pasitiki jiems paslaugas teikiančiais multidisciplininès komandos nariais. $84,5 \%$ hospitalizacijos metu laikosi ịstaigos/skyriaus taisyklių. Igalinimo procese dalyvauja $36,6 \%$ artimujų. 
Resocializacija. Iš tyrimo gautų duomenų matyti, kad po PMP taikymo stacionare $63,4 \%$ tiriamujų gavo artimųjų paramą ir palaikymą (19,7\% - dvasinę/psichologinę; $1,4 \%$ - finansinę; $43,7 \%$ - abi), tačiau $36,6 \%$ respondentų neturejo jokio artimujų palaikymo ir paramos. Institucines paslaugas gavo 97,2\% tiriamuju. Analizuojant resocializacijos procese dalyvavusių ịstaigų tinklą, pastebèta, kad paslaugas teikè psichikos sveikatos centrai (66,2\% atvejų), $29,6 \%$ - socialinès globos įstaigos ir $4,2 \%$ - savivaldybès/ seniūnijos. Didžiają dali paslaugų (79\%) sudarè medikamentinis gydymas, $2,8 \%$ - psichologinè pagalba ir $18,2 \%$ - psichosocialinè reabilitacija.

Tyrimo rezultatai parodė, kad nepakaltinamų asmenų igalinimo procese visai nedalyvavo ugdymo įstaigos, socialinių paslaugų centrai, bendruomeninès ir religinès organizacijos.

\section{Išvados}

1. Nepakaltinamų asmenų pakartotiniam nusikalstamumui ịtakūs statiniai veiksniai, susiję su asmens ir šeimos kriminaline istorija, bei dinaminiai veiksniai, susiję su asmens išsilavinimu, darbu, psichine sveikata, socialiniais ryšiais.

2. Daugiausia nusikalstamą veiką ịvykdo ir PMP priemonès skiriamos žemesnio išsilavinimo asmenims, nedalyvaujantiems darbinèje veikloje, nevedusiems ar išsituokusiems tiriamiesiems, gyvenusiems socialinès globos namuose ar su vienu iš tėvų, nepripažįstantiems psichikos sutrikimo ar medikamentinio gydymo reikalingumo.

3. Tyrimo rezultatai parodo rizikos veiksnių ịtaką tiriamųjų nusikalstamumui: $72 \%$ respondentų išsilavinimas vidurinis ir žemesnis; $49 \%$ respondentų neturi profesinès kvalifikacijos; tik 15,5\% respondentų turi nuosavą būstą; socialiniai ryšiai su artimaisiais silpni (68\% nurodè, kad ryšiai fragmentiški arba jų nèra); 92\% iki PMP taikymo gydyti psichiatrijos ligoninėse.

4. Tyrimo rezultatai parode šias menkas tiriamujų igalinimo išorines sąlygas: silpni socialiniai ryšiai ir menki dalyvavimo šeimoje bei bendruomenèje igūdžiai; mažos galimybès pasirinkti (dèl sveikatos būklès, išsilavinimo); ribota galimybė naudotis ištekliais (menka šeimos ir bendruomenès parama).

5. Rizikos veiksniai, turintys ịtakos nepakaltinamų asmenų pakartotiniam nusikalstamumui, susiję su šių asmenų igalinimu - pasirinkimų didinimu bei galimybèmis paveikti savo gyvenimą.

\section{Literatūra}

1. Jesiūnienė D. Igalinančios socialinių paslaugų organizacijos konstravimas. http://vddb.library.lt/fedora/get/LT-eLABa-
0001:E.02 2012 D_20120626_104450-48716/DS.005.0.01. ETD (2015-03-10).

2. Justickaja S., Gavėnaitė A. Recidyvinis nusikalstamumas: tyrimo galimybės ir perspektyvos Lietuvoje. http://www.teise. org/data/2009-3-justickaja-gavenaite.pdf (2015-03-10).

3. Leliūgienė I., Janušaitienė N., Baršauskienè V. Psichikos liga - depresija sergančiu žmonių socialinis iggalinimas edukacinèmis priemonèmis psichikos sveikatos centruose. http://etalpykla.lituanistikadb.lt/fedora/objects/LT-LDB0001:J.04 2009 1367168682037/datastreams/DS.002.0.01. ARTIC/content (2015-03-10).

4. Linhorst D. Empowering People with Severe Mental Illness: A Practical Guide. https://books.google.lt/books?hl=lt\&lr=\&i $\mathrm{d}=\mathrm{kLm} 2 \mathrm{GM} 5 \mathrm{~K} 7 \mathrm{w} 0 \mathrm{C} \&$ oi $=$ fnd\&pg $=$ PR13\&dq=David+Linhors $\mathrm{t},+2006,+$ Empowering + People+with + Severe+Mental+Illness $:+\mathrm{A}+$ Practical+Guide\&ots $=$ ojvtjBeI-C $\&$ sig $=\mathrm{g} 0 \mathrm{HqHeF} 8 \mathrm{ZEpK}$ $37 \mathrm{n} 3 \mathrm{PZNm} 4 \mathrm{FVkO}$ OU\&redir_esc $=\mathrm{y} \# \mathrm{v}=$ onepage $\& \mathrm{q} \& \mathrm{f}=$ false (2015-03-10).

5. Petkus A., Babachinaitė G. Kriminologinès problemos dvidešimtmečio socialinių pokyčių Lietuvoje kontekste. Jurisprudencija, 2014; 21(1):259-278. http://dx.doi.org/10.13165/JUR-14-21-1-13

6. Petrošius M., Dirgélienè I. Iggalinanti bendruomenė asmenų, grįzusių iš laisvès atemimo vietų, resocializacijos procese. http://journals.ku.lt/index.php/tiltai/article/viewFile/170/pdf (2015-03-10).

7. Ustinavičiūte L., Žukauskienė R., Laurinavičius A. Lietuvos nuteistujų pakartotinio nusikalstamumo rizikos veiksniai: oasys metodikos diskriminantinio validumo analizè. https://www. mruni.eu/upload/iblock/b40/19ustinaviciute,\%20zukauskiene,\%20laurinavicius.pdf (2015-03-10).

8. Ustinavičiūtė L. Lietuvos teisès pažeidèjų rizikos veiksnių, susijusių su pakartotiniu nusikalstamumu, analizè. http:// vddb.library.lt/fedora/get/LT-eLABa-0001:E.02 2012 D_20121115_135113-46832/DS.005.0.01.ETD(2015-03-10).

9. Ustinavičiūtè L., Laurinavičius A., Žukauskienẻ R., Bandzevičienẻ R. Kriminogeninių rizikos veiksnių palyginimas skirtingose Lietuvos teisès pažeidèjų grupèse. https://www. mruni.eu/upload/iblock/391/3_Ustinaviciute.pdf(2015-03-10).

10. Venclovienè M. Igalinimo samprata ir veiksniai socialinio darbo metodų perspektyvoje. http://www.lmaleidykla.lt/publ/023571 86/2015/2/113\%E2\%80\%93121.pdf (2015-03-10).

11. Žilinskienè L., Tumilaite R. Resocializacijos modeliai ir jų taikymas. Sociologija. Mintis ir veiksmas, 2011; 2(29):285-313.

\section{THE CONNECTION BETWEEN THE REPEATED CRIMES AND CONDITIONS FOR EMPOWERMENT OF THE IRRESPONSIBLE PERSONS}

\section{J. Navickienè, A. Liausėdas, E. Vaitiekus}

Key words: irresponsible person, repeated crime, risk factors, empowerment.

Summary

In the recent decades, many studies were conducted, which 
examined the causes of the offences and risk factors causing the repeated crime. The repeated crime is a constant tendency to commit repeated crimes and antisocial behaviour.

Factors that influence on the re-criminal behaviour are a low level of education, lack of basic skills, problems with the employment on the labour market, absence of the domicile, use of drugs and alcohol, mental health disorders and weak social relations. The essential role of these factors for the repeated crimes was approved by the results of conducted researches in the various countries. Therefore, it is grounds to believe that these factors are versatile.

The aim of the article is to reveal the connection between the repeated crimes and conditions for empowerment of the irresponsible persons. The applied methods are based on the analysis of the scientific literature and patients' documentation of Rokiškis psychiatric hospital. The study showed the influence of the risk factors on the subjects' crime and poor external conditions of empowerment for subjects. The risk factors that influence on the repeated crime of irresponsible persons are related to the empowerment of individuals - increasing choices and opportunities to influence on their lives.

Correspondence to: j.navickiene@rpl.1t

Gauta 2015-12-10

\section{KVIEČIAME PRENUMERUOTI "SVEIKATOS MOKSLŲ" ŽURNALĄ 2016 METAIS!}

Žurnalas "Sveikatos mokslai" (Index Copernicus, EBSCO host (Academic Search Complete), Gale (Academic OneFile), ProQuest (Ulrich's, Summon), Australia (ERA) 2012 Journal List (ERA ID 34962) skirtas visu specialybiu gydytojams, slaugytojams ir kitiems specialistams, spausdina mokslinius straipsnius lietuvių, anglų kalbomis. Reikalavimai straipsniams atitinka mokslo leidiniams keliamus reikalavimus.

Žurnalas kioskuose neparduodamas.

Žurnalą, kuris leidžiamas kartą per du mėnesius, galima užsiprenumeruoti visuose Lietuvos pašto skyriuose, taip pat internetu: www.post.lt

Prenumeratos kaina nesikeičia: visiems metams - 34,75 EUR (120 Lt), šešiems mẻnesiams 17,37 EUR (60 Lt), keturiems mėnesiams - 11,58 EUR (40 Lt), dviem mėnesiams - 5,79 EUR (20 Lt).

Prenumeratos kodas: 5348.

Žurnalo autoriams straipsnių spausdinimas mokamas. 